\title{
An Analytical Study of the Factors Causing Sexual Deviation as Depicted in the Buddhist Scriptures
}

\author{
Phramaha Nantakorn Piyabhani
}

Department of International Buddhist Studies College, Graduate School, Mahachulalongkornrajavidyalaya University, Thailand

Copyright@ 2016 by authors, all rights reserved. Authors agree that this article remains permanently open access under the terms of the Creative Commons Attribution License 4.0 International License

\begin{abstract}
Although it seems undeniable that most human beings are of either the male or female gender, it is also clear that there are significant numbers of individuals who are of special and somewhat unusual gender. Such individuals have often been referred to as sexual deviants. According to the Buddhist perspective, everyone has the right to be what they want, and everyone has the right to develop their mind in the direction of Enlightenment. Buddhists believe in the principle of cause and its effect, meaning here that whoever does good deeds receives good results, and whoever does bad deeds receives bad results. From the study, it has been found that: 1) There are two sets of factors, external and Kamma-related, which cause sexual deviation. The external factors include family, school, friends, environment, and social media etc. The Kamma-related factors are actions that beings have done during previous existences. Both sets of factors are very significant in this problem 2) There are a number of ways by which sexual deviants and the general population can better live together. These involve: a) social work, b) medicine, c) the law, d) the Ministry of Social Development and Human Security, and e) Buddhism. The research also suggests that all parties involved in the task of finding better ways for sexual deviants and general people to get along need to act with a high degree of integrity if those in need are to benefit.
\end{abstract}

Keywords Factors, Sexual Deviation, Kamma, Buddhist Scriptures

\section{Introduction}

In the world cycle of birth and death, it seems undeniable that most human beings are of either the male or and female gender, it is also clear that there are significant numbers of individuals who are of special and somewhat unusual gender. Such individuals have often been referred to as sexual deviants. Furthermore, in Thai society, the attitude towards sexual deviation has often been mostly understood as 'Sexual Disorder'. Even though in general Thai society is often quite tolerant of sexual deviants, in some cases it places limits on them that restrict their social and career mobility, as well as their personal happiness. Some psychiatrists from such countries as Netherlands, France, Sweden, and Denmark admit that sexual deviation is a normal issue. The behavior of these people is accepted to get married or divorced. On the contrary, Thai society has $\mathrm{s}$ negative attitude towards this issue and considers it as a disgusting issue. Some think that these people have mental illness and need a treatment from the psychiatrist. In fact, they are partial members of society in which the number is increasing constantly. Moreover, sexual deviants undeniably have various roles and responsibilities in society so that we have to understand some of their specific characteristics in order to live together peacefully.[1]

At present, although Thai society does not take violent action against sexual deviants, it does regard sex deviation as a behavior disorder. It found that the research on homosexual people in Thailand is based on four assumptions:

1. Homosexuality was evil and need solution

2. Homosexuality was pathology, abnormal or had something wrong with it

3. Homosexuality was the role of the same sex caused by the defect on the role of family member

4. Being homosexual person was a result of the defect on the role of family member.[1]

However, according to Buddhist perspective, every sex has the same rights in Buddhahood to enlightenment. Everyone: woman, man, or LGBT has the Bodhi seeds: seed of realization, seed of awakening. Everyone has the right to approach it without sexual, caste and class condition. The main problem that obstructs Buddhahood access is how much those people accumulate the Bodhi seed. In the past life of Venerable Ānanda, a great attendant of the Buddha had been a sexual deviant. However, he accumulated Bodhi seed or a perfection and was, finally, born to be Ānanda in the last life, becaming an enlightened one to eliminate the risk to be reborn as man, woman, or sexual deviant.

Therefore, Buddhism taught that the arising, existence and cessation of all things come from causes. Sexual deviation 
also does not abruptly exist, but has existed since in the old days and is likely to continue endlessly. It does not matter whether it already existed or is going to exist, the main point is when it exists, how to deal with sexually deviant behavior and it is considered as the serious problem of the global community that is facing. In some countries the sexual deviants are accepted, and permitted to live in society openly. On the other hand, those who are living in the countries which consider it as unacceptable must live secretively. Buddhism believes that everything happens from the causes; the good cause results in good outcome, the bad cause results in bad outcome. Thus, there is the question that what is the cause makes global people have deviant sexual behavior and once we know they are different, how we can welcome and live with them peacefully.

\section{Research Methodology}

The research was conducted with preliminary survey, systematic data collection, analysis and synthesis collected data to have new body of knowledge, report and distribute research results. This study is documentary research. Research methodology was as follows.

1. Study documentary data from primary source and collect data from Theravada Tipițaka, commentaries, sub-commentaries, and literary works.

2. Gather data from the secondary source comprised of books, textbooks, literatures of contemporary academicians, researches, related academic journals, journals, newspapers, etc.

3. Study, analyze and synthesize the collected data following the objectives

4. Summarize data to report research result

\section{Research Findings}

The results indicated that there are two key factors causing sexual deviation:

\subsection{External Factors}

The key components of external factors are as follows:

\subsubsection{Family Factor}

Family is one of the factors stimulated sex transmutation conditions. It might cause by environment and the wrong gender upbringing in family. Being too close to a mother give more chance to children to absorb a femininity from mother. Moreover, the school environment, having friends who have feminine characteristic might cause deviational behavior. Generally, sexually deviant behavior begins during childhood and early adolescence period. However, the behavior would be obvious in late adolescence to early adulthood. During childhood, children between four and five years of years old begin to have behavior similarly to the girl. It would be noticeable in pre-school age children that they become delicate, for instance, starting to wear girl costumes, and playing with dolls rather than participating in sports. In case of children with unclear behavior, it is necessary to notice the behavior reflected in their ideas. For example, they do not play a game the boy would love to but prefer to draw the girl cartoon, love pink color, and hate fighting or violence.

First of all, parents should change the attitude, accept what their children are, and not try to change or solve them as it would pressure them. As a result, they would not understand themselves when they grow up.[2]

Regarding upbringing, the psychiatry give a significant importance to this respect because it influences sex transmutation. The upbringing that does not match the child's sex might create problems. For instance, a cute boy who is brought up with gentleness and has full attention from the family members is likely to take female characteristic, or the family that wants the baby girl but has the baby boy instead might treat him as a girl. In some cases, the adult thought that the child has an ability of the opposite sex; such as the boy who is good at dancing would get the support to do dance activity unintentionally. Finally, the boy enjoys the girl's activities. This is partial cause of gender identity disorder.[2]

Another cause found is that the children with sexually deviant behavior has bad relationship with the father, such as not too close with the father or is blamed by the father during the early age. However, the father should not be emphasized because it is only a partial cause. Furthermore, in the family that has lot of nephews, grandmother or grandfather might want to have a niece. Thus, they dress him up with skirt, as a girl. This is one of the causes of deviational behavior.

\subsubsection{Physical Environment}

Environment is classified into two types: physical and mental environment. Physical environment here focuses on media consumption. Television media has more influence than radio media because it could be perceived via visual and audio content. Thus, television plays or game shows that normally presents the transgender as a comedian character who expresses aggressive action, has influence on the boy's imitation behavior.

Internet is the boundless network that presenting the variety perspectives such as videos on You-tube. It is a way that children may access videos presenting various sexual behaviors of people. This causes the imitation of children in which the parents should provide them an accurate and suitable advice.

Printing media or academic journals arouse or encourage resistance to transgender. Parents who consume this media would be against transgender, and pass on this idea that being transgender is wrong, and a shame to their son. Thus, the son who is in the risk group would resist the way parent brought him up and express the aggressive behavior against the upbringing of parent. 


\subsubsection{Mental Environment}

A deviational behavior of individual caused by mental change, particularly when having continual severe emotional damage and, finally is unable to stand the condition. Relevant factors that lead to deviational behavior are as follows:

1. Mental oppression: Person who has mental oppression has high stress and is suffer through this time and tries to avoid this condition. If the person applies creative ways to avoid this state of mind, it would help to resolve problem. Conversely, if the person uses the opposite way, it would cause more problems.

2. Sensibility: The sensible person would react to the stimulus differently. He or she would easily and frequently impacted by mental damage. As a result, there is more chance of deviational behavior.

3. Pressure: It simply causes mental deceleration. When the person is stress, he or she is discourage and ignores what needs to do. In a serious case, mental disorder could happen.

4. Aggression: It has close relationship with deviational behavior in which always had pressure underneath. Pressure results in mental disorder and, finally, deviational behavior.

\subsubsection{Genetic Factor}

There are several factors identified that sexual deviation in children caused by heredity.

Internal factor of children that is the result of biological influence, which is the scientific assumption that has not yet proved, that trans kids are identified by sex chromosome embed in their genes. There is only one pair of sex chromosome in human body; XY chromosome. The boy who has Klinefelter syndrome would have XXY chromosome in which make them to be taller than an average height, have abnormal breast like a girl, have small testis so that he has low sexual desire or has no sex appeal.[3]

Regarding heredity, if a family member has gender identity disorder, other family members are likely to have inherited genes of gender identity disorder or some diseases such as Adrenal cortex diseases in which over-produced testosterone. If a girl has this disease, she would look like a boy. Moreover, it might happen to other organs while being in the womb and result in the abnormal sex chromosome. After the birth, the baby has an organ dysfunction. In some cases, it is an organ ambiguity in which could not specified whether it is penis or vagina. Therefore, parents are confused whether to bring them up as a boy or a girl.

\subsection{Kamma Factors}

Buddhism taught that everything has cause and effect. According to Kamma principle, everyone in this world commits deeds; both good and bad deed that result in good or bad consequence. For this reason, sexual deviation problem, of course, is the result of bad deed; having intention of sexual misconduct and infidelity in other's marriage life. This act is considered as a corruption; stealing, stealing the virgin that the owner or guardian does not allow. It is to say that a sinful intention toward the other sex led the person to the underworld, taking rebirth as a castrated male beast or a human with sexual problem such as being sexual deviant, bisexual, non-sexual, human who is cut sexual organ, or has accident that affected sexual organ.

\section{The factors causing sexual deviation could be analyzed based on Theravada Buddhist scripture as follows}

\subsubsection{Kamma in the Vinaya Pițaka}

The term "Kamma" refers to an action related to body, speech, and mind both in good or bad respect. Kamma, according to the Vinaya scripture emphasizes on a person who was born with weak meritorious deed performed in the past, so he/she was born as a forbidding human; sexual deviant who is not allowed to be ordained according to Buddhism.

The evidence in the Vinaya Pitaka discloses that sexual deviant (in Pāli; panḍaka) has existed since in Buddha Era. Lord Buddha led down the discipline (firs pārājika rule) to prohibit the monk from having sexual intercourse. Sexual intercourse is not only prohibited with female but also with transgender and the beast. For example, there was a monk who had sexual relationship with sexual deviant. Lord Buddha said: "That monk commits the pārājika rule" (he must leave the monkhood).

In the Vinaya Pițaka,[4] sexual deviants are classified into three categories:

1. Manussa Pandaka or human sexual deviant

2. Amanussa Pandaka or non-human sexual deviant

3. Tiracchāna Panḍaka or sexual deviant beast

Manussa Pandaka or human sexual deviant means all male and female human who has sexual deviation. Amanussa Pandiaka or non-human sexual deviant herein refers to some kinds of non-human being such as Deva from Cātummahārājika heaven (the lowest class heaven closing to human realm) who has similar livelihood to human. Tiracchāna Pandiaka or sexual deviant beast stands for the general animal that was born with the result of sin. It is obvious that Lord Buddha emphasized on the three types of Pandaka who was born from the result of bad deed. He prohibited the monk to have sexual relationship with those people or animals. Pandaka appearing in the Vinaya reflected the consequence of what they had committed in the past lives.

\subsubsection{Kamma in the Sutta Pițaka}

The Sutta Pițaka specifically mentions the individual and the Kamma he had committed in the past. It mentions the person who commits sinful deed, which is the reason to be reborn as a transgender in the next life. Kamma is the body action that has an intention of having sexual relationship with person who belongs to someone else; both who has wife or husband while another one does not. In the 
Mahānāradakasapa jataka[5] it referred to the consequence of Kamma from having sexual relationship with the wife or husband of other that the person would have torment in underworld everlasting. In the further lives, due to the remaining result of bad Kamma, it yielded such result by being born as the male beast that was castrated and was unable to reproduce in every life. Finally, he would bear to the human who had sexual deviation, was castrated (eunuch), or had an accident and lost the sexual organ. Besides, there was the story of Bhikkhuni Isidāsi[6] who roughly narrated her past Kamma that she committed sexual misconduct. In her past life, she was a goldsmith living in Erakacaccha City, who was rich and had sexual relationship with the wife of other man. After his death, he had been in the underworld for a long time and after that, was born as the beast in the next three lives: a monkey who was bitten sexual organ, a goat who was cut sexual organ, and a castrated ox. Afterward, he was born to sexual deviant, and after that, born as a woman in the poor family that had lot of debts. In the Buddha Era, she was born in a millionaire family named Isidāsi. With her remaining sin, she got divorced with her husband three times because he had sexual relationship with wife of other. Finally, she was ordained as Bhikkhuni, became enlightened after the seventh day of her ordination, and was free from all sin and free from the cycle of life.

\subsubsection{Kamma in the Abhidhamma Pițaka}

The Abhidhamma is the scripture that does not mention a specific individual as in the Vinaya and Sutta, but focuses on the individual state of mind. Abhidhamma regard that everything derive from the mind. Thus, to end everything, it should start from the mind. Therefore, psychiatrists and persons who study Buddhism share a common definition of sexual deviation as the change of mind. It does not mean that a transgender person has a mental problem or is insane. When there is a problem with the mind, problem-solving should focus on the mind.

Questioning which of the Kamma resultant consciousness (in Pāli; vipāka citta) the sexual deviants were born to, it depends upon what kind of Kamma the individual had committed in the past life. Bad or sinful deed from the past life (according to Sutta Pițaka), having sexual relationship who belongs to other bear Kamma-result to be born in the next life. For this reason, human and animal would be born in good or bad condition depended on the consequence of the deed that led them to the different spheres. In this case, the researcher would specifically study on the consciousness that originated human, particularly the sexual deviants.

\section{The Human-Original Consciousness is Classified into 9 Categories as Follows:}

1. One Upekkhāsantiraṇakusalavipāka citta - wholesome resultant consciousness[7]

2. Eight Mahāvipāka cittas-great wholesome resultant consciousness
Upekkhāsantiranakusalavipāka citta refers to the consciousness that is the resultant of wholesome consciousness, but it is powerless (Dubbalakusalavipāka citta) because it is the consciousness rising with no three moral root minds, to wit: Non-greed, Non-hatred, and Non-delusion. Person who was born from the said kind of consciousness called Ahetukapuggala-a person who was born from a powerless consciousness because did not have those three minds. Mahāvipāka citta refers to the wholesome resultant consciousness that is stronger (Balavakusalavipāka citta) because it associates with the two moral root minds: Non-greed and Non-hatred. The person who was born from these two minds called Dwihetukapuggala. And because it associates with the three moral root minds: Non-greed and Non-hatred and Non-delusion. The person who was born from these three minds called Tihetukapuggala.[8]

To make it more obvious, the researcher imitates the figure of 9 categories of consciousness as follows:

\section{This first type of consciousness called}

Upekkhāsantiraṇakusalavipāka citta. It is so called because it is one of the 18 Ahetukacitta (18 rootless minds) in which is the mind without the three good causes as mentioned above, and it is the only mind in this group that make the sentient being to be born in the sense spheres where consist of human realm and devas from Jātummahārājika class. Some humans and devas who were born from this mind called Ahetukapuggala, as they were born with powerless moral-resultant consciousness

(Upekkhāsantiraṇakusalavipāka citta).

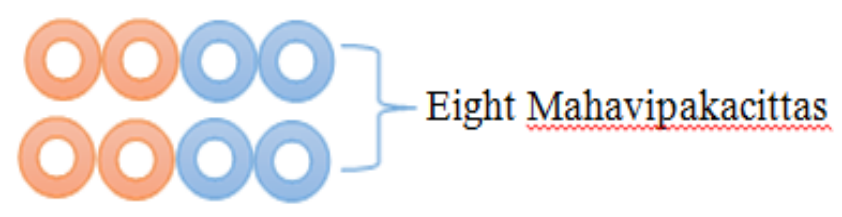

Eight kinds of this mind are called Sahetukacitta, it is so called because the mind consists of Mahākusalahetu-great moral root minds ( 2 and 3 moral roots mind as mentioned above). First four minds grouped in orange color are the mind of person who was born from the great three roots called Tihetukapuggala. The later four are the mind of person who was born with the great two roots called Dwihetukapuggala. All eight types of this mind bear the great moral result to sentient being to be born in a sense planes where consist of human and devas (except some deva from Jātummahārājika class). The birth consciousness of sentient being who was born in this world called Tihetukapatisandhi (birth consciousness consists of three moral roots) and Dvihetukapatisandhi (birth consciousness consists of two moral roots) since it was born from the first and the last four Mahāvipākacittas; the first four types make them be the great wise and the second make them be middle wise. 


\subsection{Birth Period of Human/Animal}

Birth process of sentient being consists of the ongoing three periods or three Kala influences by the power of Kamma resultant in which lead the sentient being to be born.

1. Cutikāla (Death period)

2. Pațisandhikāla (Birth period)

3. Pavattikāla (Between birth to death period)

All three periods are continual, when the death period come to sentient being. Vipākacitta (the Kamma consequence that the one had committed) is both good and bad Kamma. If both are of heavy Kamma that is Janakakamma (kamma lead to the birth) happens in the birth period immediately. After the birth of sentient being, it is the time between the Patisandhikāla to Cutikāla called Pavattikāla. During this time, the sentient being would grow and commit good as well as bad deeds until the death period arrive.

\subsection{Chart of Life Cycle of Human/Animal}

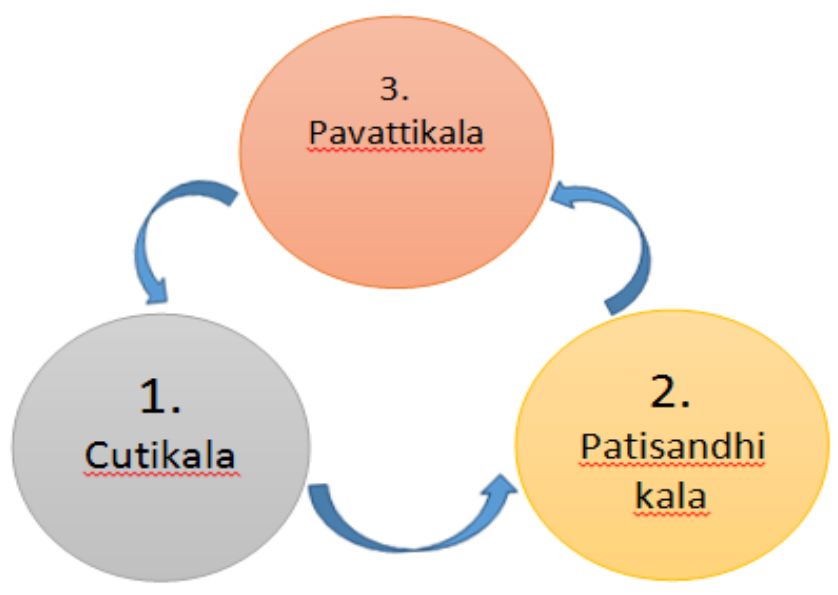

The figure presenting cycle of life or the process of death and birth of sentient being without an interruption. It is to say the sentient being would be reborn immediately after its death, not waiting or wandering for the rebirth. This is because Vipāka or the result of what Kamma the sentient being has done is ready to be effective in the birth period immediately. Afterward, it would be the growth process until the sentient being dies. During the birth to the death period (Pavattikâla), the sentient being is sill to perform both good and bad conducts endlessly.

In short, when defilement, Kamma, and Kamma result still exist, the sentient being would remain in the cycle of life. Whenever they end, Cutikāla, Pațisandhikāla, and Pavattikāla would also completely end.

\subsection{Birth Evolution of Human/Animal}

The Mahātanhasankhayasutta [9] explained that the cause of birth consists of three factors: 1) mother and father living together, 2) mother has menstruation, and 3) creature come to be born. When these three factors assemble, the process of pregnancy arises. After that, the power of Kamma called Kammajarupa-the three groups of form caused by Kamma firstly, happen:

1. Kāyadasakakalāpa-the form derives from the power of Kamma to vary the cells of mother and father to become a form of body (with no arms and legs), called sensitive matter, including these ten forms: Earth-element, Water-element, Air-element, Fire-element, Color, Odor, Taste, Sap, Sensitive matter, and Life.

2. Bhāvadasakakalāpa - the form derives from the power of Kamma to identify the gender: male or female, including these ten forms: Earth-element, Water-element, Air-element, Fire-element, Color, Odor, Taste, Sap, Gender, and Life.

3. Hadayadasakakalāpa - the form derives from the power of Kamma to basis of consciousness, including these ten forms: Earth-element, Water-element, Air-element, Fire-element, Color, Odor, Taste, Sap, Seat of consciousness, and Life.[10]

Indakasutta[11] described the development of form or body that in the first stage, the form is delicate, round and clear. It has the same size with the oil drop on the wool after the third shake, called Kalala. In the next 7 days, Kalala would become cloudy, its color likes water watching meat, and its shape likes tin, called Abbuda. Afterward, it become a small piece of flesh, called Pesi. Then, it develops to be bigger called Ghana. In week 5, there are five knots namely; two arms, two feet, and one head. Then, hairs, furs and nails would grow respectively.

\subsection{Mind Leads to Sexual Deviants}

As stated earlier that Kāmasugatibhumi 7-Human spheres, and six deva spheres applied 9 Vipākacittas: Upekkhāsantiranakusala Vipākacitta 1 and Mahāvipākacitta 8. All these 9 Vipākacittas could not emerge without the accumulation of Kamma in the mind. The accumulated Kamma would be strong or not depend upon the intention. And the determined intention to perform any Kamma complete as Kammapada (course of action), such action is considered as Janakakamma (reproductive Kamma). This reproductive Kamma is able to produce one of those 9 Vipākacittas after the death to be born in the new world immediately, other actions with small intention could not bear a result. The good or bad intention of Kamma performed by human being would yield a Kamma result bringing them to the new plane, new appearance, and new complete or incomplete gender, or bisexual, or had no gender, sexual deviant and transgender etc.

To the question that which of the Kamma causes sexual deviation in human and such person was born with which consequence of mind (Vipākacitta), which bad intention would intend to sexually violate other or to sexually violate the person who belongs to other. The person who belonged to other might be defined as:

1. A person who had husband

2. A person who had wife

3. A person who does not have wife or husband but the parent or guardian look after him/her. 
The successful intended action is course of action (Kammapada), which is sexual misconduct (Kāmesumicchācāra). On the other hand, if it fails, it would be considered the normal Kamma that affects in the Pavattikāla. The consequence of sexual misconduct leads the animal to be in the underworld everlasting. After the underworld life, Vipākacitta would yield a result to be reborn as the male beast who has problem with sexual organ such as is cut out, is castrated, loses it in an accident, loses its origin and could not reproduce any longer. After the beast life, with the remaining Kamma, it would go to the sense sphere: being reborn as human from the first type of Kamma resultant consciousness (Vipākacitta) known as Upekkhāsantiraṇakusala Vipākacitta. Although it is meritorious mind, but it itself is powerless Kamma resultant (Dubbalakusalavipāka citta) that caused by misconduct in the Third percept. Moreover, there is no strong roots of good action (non-greed, non-hatred, non-delusion) accompanies with it. With this cause, the person who was born from this mind would born to be sexual deviant or became deviational person later. The consequence could be classified as follows:[12]

1. Born to be the blind, the deaf, the person without nose, the mute, the foolish, or the mad person. (in Pāli;

Jaccandhajacicabadhirajaccaghanakajaccamugajacca jalajaccummattaka)

2. Born to be two-gender person (Ubhatobyanjanaka)

3. Born to be sexual deviants (five types of sexual deviants)

4. Born to have no sex(Napunsaka)

5. Born to be tongue-tied person (Mamma)

Item 2, 3, and 4, in particular, that caused by Kamma resultant of bad action power related to sexual misconduct, interfering the good action that lead to human rebirth; it lessens the power of good action and has lighter power so that results in the mismatch between gender and mind, when he was born or afterward, such as the putrid sexual organ that needs to cut off, is cut by the woman, is castrated, or loses sexual organ in accident. In case of woman who became the deviant as a lesbian. Let us understand that it caused by the unwholesome action in sexual misconduct as well. The said rebirth called a powerless conception in which could not be born as superior deva, but an inferior deva or an incomplete human who had mental or physical disorder. This type of mind is called Upekkhāsantiraṇakusalavipāka citta.

Regarding the other 8 Mahāvipakacitta, they are the powerful good minds without the interference of bad action so that it lead to the rebirth as a perfect person with the four courses of existence, both physical and mind completion, including having middle wisdom as well as the great wisdom and be able to develop oneself to the enlightenment.

In short, factors causing sex deviation are classified into two categories:

1. External factors

\section{Internal factor}

External factors consist of supportive internal factors which are the upbringing of family, environment, and heredity etc. Internal factor is Kamma. Both factors are related and resulted in sex deviation existing in all societies, genders, and ages. Some were born with the deviation while some admitted when they grew up or concealed it for all their life. All of these caused by sexual misconduct. The consequence of this misconduct results in mind consequence in which a person was born to have mind that is inconsistent with gender; having male appearance but the mind is female or having female appearance with the mind as a male since either was born or afterward. The 11 results of Kāmesumicchācāra (sexual misconduct) the person might have are:

1. Have lot of haters

2. Be malicious

3. Be an impoverished person

4. Be a deprived person

5. Be a woman

6. Be sexual deviant

7. Be a man in the inferior family

8. Be embarrassed

9. Have physical disorder

10. Have lot of concerns and anxiety

11. Be separated from the loved one[13]

All of these are the results of sexual misconduct so that the person would be reborn with sexual dysfunction. With all these consequences of moral infringement, everyone should be aware of the third moral precept: have sexual relationship only with the partner, not with other or the other's partner. With this behavior, number of people with sexual deviation will decrease. For those who are transgender, they have to accept the fact and, importantly, society must give them a chance and allow them to live in society as same as other people, not look down on them, or restrict their common rights or liberty in order to live together peacefully.

\section{Conclusions}

Sexual deviation is a state when a person has sexual desire, attitude as well as sexual behavior but express it inappropriately and differently from other people in society. Sexually deviant behavior as found in society is classified into six categories: 1) Hermaphrodite 2) Transvestite 3) Transsexual 4) Heterosexual 5) Bisexual and 6) Homosexual. In the Vinaya Pitaka, sexual deviation could classified into three types: 1) Human sexual deviant 2) Non-human sexual deviant and 3) Sexual deviant beast Moreover, in the Vinaya commentaries, sexual deviants are grouped into five categories based on their action: 1) Asitta Pandaka 2) Usuya Pandaka 3) Opakamika Pandaka 4) Pakkha Pandaka and 5) Napunsaka Pandaka. However, this commentary classified Pandaka into three groups: 1) The group of homosexual 
which are Asitta Pandaka and Pakkha Pandaka, 2) The group of sexual pervert which is Usuya Pandaka, and 3) The group of no sign of sex which are Opakamika Pandaka and Napunsaka Pandaka.

In the Sutta Pitaka, it mentioned the consequence of violating the third precept or violating other's wife. The sample is the past action of Ven. Ananda who violated the third precept. With the consequence, he was born in the underworld everlasting and paid for the Kamma respectively. Another sample is the story of Bhikkhuni Isidāsi who once was born as a man and had sexual relationship with other's wife.

The Abhidhamma Pitaka did not specifically mention the individual as the Vianaya and Sutta Pitaka. However, it focused on the state of consciousness of the individual. Abhidhamma considered that everything happened from the mind and it is the variable that transformed or deviate the body or mind in which is the result of the actions in the past.

Factors causing sex deviation could be concluded into two types:

1.External factors: They refer to the family factor such as the upbringing, routine life e.g. too close to the mother, having friends, environment which consist of physical environment e.g. online media consumption, internet, and mental environment e.g. depression, aggressiveness, and sensitivity. It also includes heredity.

2. Kamma factors: Buddhism explained that everything comes from causes. If there is a cause, there is consequence, which means the person has got what he has done. In Buddhist perspective, sexual deviation derives from infringed on the third precept. The Kamma related to this issue exists in Vinaya, Sutta, and Abhidhamma Pitaka.

The guidelines for sexual deviant people to live in the society required the integration of principle, method, and objective that aims to the efficient practice. It should start with create the understanding of human conception, both woman and man or the third sex in which originated from the cause. Buddhism clarifies that being born as human is difficult, but if so, it is precious. Person who is born as a third sex, he/she possibly be tortured by society and the close people in the past. Nevertheless, at present, society more accepts the different sex, in which they are not different from man or woman in general.

Even though being born with sex deviation caused by bad actions in the past, everyone has different good and bad actions and cannot go back to resolve them. Everyone, thus, be able to better the life with new actions or Kamma because the good future based on the current actions. According to Buddhist doctrine, it teaches to see people's value from the action. Person who behaves good deed by physical, verbal, and mental action and not violate morals deserves the respect, praise, and life advancement. On the contrary, if the person acts in disgusting manner violating moral, he is more hateful than a person with gender dysfunction.

People with sexual deviation who recognize good and bad, observe the precept, live the life carefully as in the past life, they will be reborn in the good world after death and have a complete sex. Therefore, performing good Kamma constantly is the most significant thing of human life.

\section{REFERENCES}

[1] Doungkaew Tunjira, Factors Affecting Sexually Deviant Behavior of High-Level Vocational Students (Thai), Vocations Education Commission, Ratchaburi, (dissertation), Graduate School: Silpakorn University, 2013.

[2] Sumalee Suaysa-ard, Sex Study, (Thai), (Bangkok: V. Print LTD., 2013

[3] The Center of Research and Sex Study Development, Medical Science Institute, Chulalongkorn University, (Thai), Sex Knowledge for Counselor, Bangkok: Chulalongkorn Press, 2011.

[4] Mahachulalongkornrajavidyalaya, Mahavibhanga of Vinaya Pitaka, Vol. II, (Thai Tipitaka (Mahachulalongkornrajavidya laya Ed., Bangkok, 1996.

[5] Mahamakuttarajavidyalaya, Jataka, Vol.V, (Thai). Mahamakuttarajavidyalaya Ed. Bangkok: Mahamakuttarajav idyalaya, 2003

[6] Mahamakuttarajavidyalaya, Therigatha, Vol. 26, (Thai Tipitaka), Mahachulalongkornrajavidyalaya Ed., Bangkok, 1996.

[7] Wat Gaoboran Dhamma School, (Thai), Curriculum for Recitation Culaabhidhammikatri, Bangkok: Liang Chiang Publishing, 2001.

[8] Culaabhidhammikatri, Bangkok: Liang Chiang Publishing, 2001.

[9] Mahamakuttarajavidyalaya, Majjhimanikaya, Vol.12, (Thai Tipitaka), Mahachulalongkornrajavidyalaya Ed., Bangkok, 1996.

[10] Anuruddha Acariya Bhadanta, A Manual of Abhidhamma, ed. By Narada Maha Thera, 4th revised ed., Kuala Lumpur: The Buddhist Missionary Society, 1979.

[11] Mahachulalongkornrajavidyalaya, Samyuttanikaya, Vol. 15, (Thai Tipitaka), Mahachulalongkornrajavidyalaya Ed., Bangkok, 1996.

[12] Abhidhammajotikavidyalaya, (Thai), Mahachulalongkornrajavidyalaya University, Vithimuttasangaha Bhumijatukaka and Patisontijatukaka, Chapter 5 Vol.1, 2010.

[13] Online available: http://www.abhidhamonline.org/aphi/p5/072.htm. (2 July 2015). 